Levchuk-Vorontsova T. O. The study of the prevalence and impact of polymorphism of the C/T gene ACTN3 (RS1815739) in the physical development of children born with low birth weight. Journal of Education, Health and Sport. 2020;10(11):114-136. eISSN 2391-8306. DOI http://dx.doi.org/10.12775/JEHS.2020.10.11.012

https://apcz.umk.pl/czasopisma/index.php/JEHS/article/view/JEHS.2020.10.11.012

https://zenodo.org/record/4282903

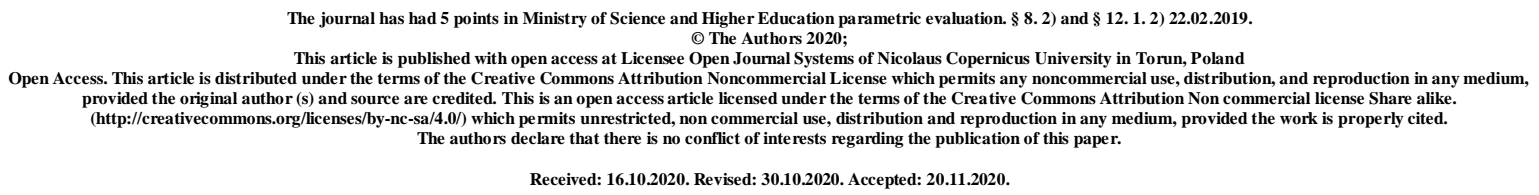

UDK 616-053.31-056.253:612.65]:575.174.015.3

\title{
THE STUDY OF THE PREVALENCE AND IMPACT OF POLYMORPHISM OF THE C/T GENE ACTN3 (RS1815739) IN THE PHYSICAL DEVELOPMENT OF CHILDREN BORN WITH LOW BIRTH WEIGHT
}

\author{
T. O. Levchuk-Vorontsova
}

\section{Zaporizhzhia State Medical University, Zaporizhzhia, Ukraine}

Levchuk-Vorontsova T. O., MD, Assistant of the Department of Children Diseases, Zaporizhzhia State Medical University, Ukraine; 28A, Novgorodskaia street, Zaporizhzhia, 69076; Tel .: +380674352467, e-mail: tatyana0702@gmail.com; ID orcid 0000-0003-0557-6714

\section{Abstract}

The work aims at studying the prevalence and influence of polymorphism of the C/T gene polymorphism of ACTN3 gene (rs1815739) on the physical development of children born with low body weight.

Materials and methods of research. To study the C/T polymorphism of the ACTN3 gene (rs1815739), 170 newborns were examined. Newborns were divided into 4 groups depending on birth weight: Group I - 50 premature babies weighing 1500-1999 grams (1776.26 \pm 20.06 grams), Group II - 64 premature babies with birth weight 2000-2499 grams (2225.31 \pm 19.46 grams), group III - 25 children with normal gestational age at birth, but with intrauterine growth retardation $(2105.00 \pm 56,41)$, group IV (control group) - 31 children with normal gestational age and birth weight more than 2500 grams (3009.03 \pm 73.04 grams). Genotyping was performed by polymerase chain reaction according to the instructions 
(Applied Biosystems, USA) using total DNA samples isolated from whole venous blood using a set of reagents "SNP-Screen" (manufactured by "Syntol") on the CFXteTM RealTime PCR amplifier (Bio-Rad Laboratories, Inc., USA).

Results. In all studied children, the frequency of detection of $\mathrm{C}$ allele polymorphism of the C / T gene polymorphism of the ACTN3 gene (rs1815739) was 51.47\%, T allele $48.52 \%$, The frequency of genotypes had the following distribution: CC-30.59\%, TT$26.65 \%$, CT-41.76\%. In this case, in group I was the following distribution of alleles and genotypes: alleles $\mathrm{C}$ and $\mathrm{T}$ were detected in the ratio of $46.67 \%$ to $53.93 \%$, genotypes SS$32.00 \%$, TT-28.00\%, ST-40, 00\%, in group II alleles - C-51,56\%, T - 48,44\%, genotypes CC $28,13 \%$, TT-25,00\%, CT - 46,88\%, in group III - allele C was significantly more often registered than $\mathrm{T}(68.00 \%$ vs. $32.00 \%, \mathrm{p}<0.05)$ and genotype TT - more often than CC and CT $(52.00 \%$ vs. $16.00 \%$ and $32.00 \%$ ). In IV (control) group there was the following distribution of the frequency of alleles and genotypes of gene polymorphism: allele $\mathrm{C}$ $40.00 \%$, allele T $-60.00 \%$, genotype CC - 38.71\%, genotype TT - $19.35 \%$, genotype CT $41.93 \%$. The lowest monthly values of body weight and weight gain were associated with the TT genotype of the ACTN3 gene (rs1815739) in preterm infants and children with normal gestational age at birth, but with intrauterine growth retardation in the first half, and among children in the comparison group - in the second half, but the overall weight gain for 12 months had no genotypic dependence. Premature infants (observation groups I and II) with the TT genotype of the ACTN3 gene (rs1815739) had unevenly lower body lengths during the first year of life, while children with normal gestational age at birth, but with intrauterine growth retardation lagged behind in their growth in the first year, and children from the control group - in the second half. The total annual increase in body length for the first year of life in all children with the TT genotype was the lowest and amounted to in the first group $28.50 \pm 1.03 \mathrm{~cm}$, in the second $-24.03 \pm 0.93 \mathrm{~cm}$, in the third $-25.50 \pm 1.04 \mathrm{~cm}$, in IV -23.00 $\pm 0.98 \mathrm{~cm}$. A probable positive correlation was found between the duration of breastfeeding and the monthly increase in body length in children with the TT genotype of the ACTN3 gene (rs1815739): $\gamma=0.58, \gamma=0.76, \gamma=0.61$ from the I, II and III observation groups, respectively.

Conclusions. It was found that the TT genotype of the ACTN3 gene (rs1815739) in children is associated with their uneven physical development in the first year of life and significantly lower rates of body length gain in 12 months, and long-term breastfeeding, especially premature babies and children with delayed fetal development, their normal growth. 
Key words: children; physical development; body weight; length; polymorphism; genotype.

\title{
ВИВЧЕННЯ РОЗПОВСЮДЖЕНОСТІ ТА ВПЛИВУ ПОЛІМОРФІЗМУ С/Т ГЕНА ACTN3 (RS1815739) НА ФІЗИЧНИЙ РОЗВИТОК ДІТЕЙ, НАРОДЖЕНИХ 3 \\ МАЛОЮ МАСОЮ ТІЛА
}

\author{
Т. О. Левчук-Воронцова
}

Запорізький державний медичний університет, Запоріжжя, Україна

\section{Резюме}

Мета роботи: Вивчити розповсюдженість та вплив поліморфізму гена ACTN3 (rs1815739) на фізичний розвиток дітей, народжених з малою масою тіла.

Матеріали та методи дослідження. Для вивчення поліморфізму С/T гена ACTN3 (rs1815739) було обстежено 170 новонароджених дітей. Діти були розподілені на 4 групи в залежності від ваги при народжені: I група - 50 передчасно народжених

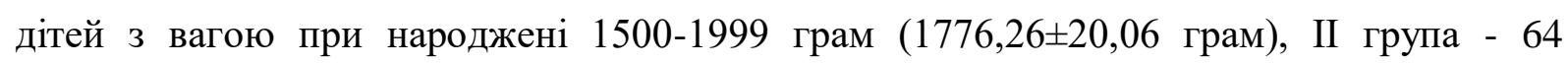

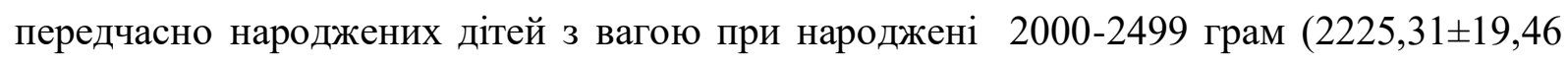
грам), III група - 25 дітей 3 нормальним строком гестації при народжені, але 3 затримкою внутрьошноутробного розвитку $(2105,00 \pm 56,41)$, IV група (контрольна) - 31 дітей 3 нормальним строком гестації і вагою при народжені більше 2500 грам (3009,03 $\pm 73,04$ грам). Генотипування проводилося методом полімеразної ланцюгової реакції згідно з інструкцією (Applied Biosystems, USA) 3 використанням зразків тотальної ДНК, виділеної з цільної венозної крові з використанням набору реагентів «SNP-Скрін» (виробник «Syntol») на ампліфікаторі CFX96TM Real-Time PCR Detection Systems («Bio-Rad laboratories, Inc.», USA).

Результати. У всіх досліджених дітей частота виявлення алеля С поліморфізму гена поліморфізму C/T гена ACTN3 (rs1815739) склала 51,47\%, алеля T - 48,52 \%., частота зустрічаємості генотипів мала наступний розподіл: СС-30,59\%, ТТ- 26,65\%, СТ-41,76\%. При цьому, у І групі був наступній розподіл алелів та генотипів: алелі С та Т були виявлені в співвідношенні 46,67\% до 53,93\%, генотипи СС-32,00\%, ТТ-28,00 \%,СТ- 40,00\%, у ІІ групі алелі - С-51,56\%, Т - 48,44\%, генотипи - СС 28,13\%, ТТ25,00\%, СТ-46,88\%, у III групі - алель С достовірно частіше реєструвалась, ніж Т 
$(68,00 \%$ проти $32,00 \%, \mathrm{p}<0,05)$ і генотип ТТ - частіше, ніж СС та СТ $(52,00 \%$ проти $16,00 \%$ та 32,00\%). В IV (контрольній) групі був такий розподіл частоти алелів і генотипів поліморфізму гена: алель С- 40,00 \%, алель Т- 60,00\%, генотип СС- 38,71\%, генотип ТТ - 19,35\%, генотип СТ-41,93\%. Найнижчі щомісячні показники маси тіла та iii приросту асоціювались із генотипом ТТ гена АCTN3 (rs1815739) у передчасно народжених дітей та дітей зі ЗВУР у першому півріччі, а серед дітей групи порівняння - у другому півріччі, проте загальні показники приросту маси тіла за 12 місяців не мали генотипової залежності. Передчасно народжені діти (I та II групи спостереження) 3 генотипом ТT гена ACTN3 (rs1815739) мали нерівномірно менші показники довжини тіла впродовж першого року життя, в той час як діти зі ЗВУР відставали в своєму зростанні в першому, а діти з групи контролю - у другому півріччі. Загальний річний приріст довжини тіла за перший рік життя у всіх дітей з генотипом ТT, був найнижчим

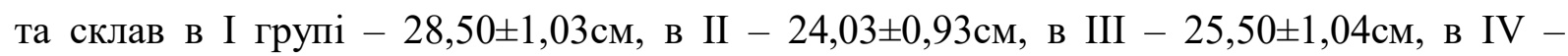
$23,00 \pm 0,98$ см. Встановлена вірогідна позитивна кореляційна залежність між тривалістю природнього вигодовування та щомісячним приростом довжини тіла у дітей 3 генотипом ТT гена ACTN3 (rs1815739): $\gamma=0,58, \gamma=0,76, \gamma=0,61$ з I, II та III груп спостереження, відповідно.

Висновок. Встановлено, що генотип ТT гена ACTN3 (rs1815739) у дітей асоціюється 3 їх нерівномірним фізичним розвитком на першому році життя та достовірно меншими показниками приросту довжини тіла за 12 місяців, а тривале природнє вигодовування, особливо передчасно народжених дітей та дітей із затримкою внутрішньоутробного розвитку, сприятиме їх нормальному зростанню.

Ключові слова: діти; фізичний розвиток; маса тіла; довжина; поліморфізм; генотип. 


\title{
ИЗУЧЕНИЕ РАСПРОСТРАНЕННОСТИ И ВЛИЯНИЯ ПОЛИМОРФИЗМА С/Т ГЕНА АСТN3 (RS1815739) НА ФИЗИЧЕСКОЕ РАЗВИТИЕ ДЕТЕЙ, РОДИВШИХСЯ С НИЗКОЙ МАССОЙ ТЕЛА
}

\author{
Т. О. Левчук-Воронцова
}

\section{Запорожский государственный медицинский университет, Запорожье, Украина}

\section{Резюме}

Цель работы: Изучить распространенность и влияние полиморфизма гена ACTN3 (rs1815739) на физическое развитие детей, рожденных с низкой массой тела.

Материалы и методы. Для изучения полиморфизма С/T гена ACTN3 (rs1815739) было обследовано 170 новорожденных детей. Дети были разделены на 4 группы в зависимости от веса при рождении: I группа - 50 недоношенных детей с весом при рождении 1500-1999 г (1776,26 = 20,06 грамм), II группа - 64 недоношенных детей с весом при рождении 2000-2499 грамм (2225,31 \pm 19,46 грамм), III группа - 25 детей с нормальным сроком гестации при рождении, но задержкой внутриутробного развития $(2105,00 \pm 56,41)$, IV группа (контрольная) - 31 детей с нормальным сроком гестации и весом при рождении более 2500 грамм (3009,03 \pm 73,04 грамм). Генотипирование проводилось методом полимеразной цепной реакции согласно инструкции (Applied Biosystems, USA) с использованием образцов тотальной ДНК, выделенной из цельной венозной крови с использованием набора реагентов «SNP-Скрин» (производитель «Syntol») в амплификаторе CFX96TM Real-Time PCR Detection Systems («Bio-Rad laboratories, Inc.», USA).

Результаты. У всех исследованных детей частота встречаемости аллеля С полиморфизма гена полиморфизма С / Т гена ACTN3 (rs1815739) составила 51,47\%, аллеля T - 48,52\%., частота встречаемости генотипов имела следующее распределение: CC-30,59\%, ТT- 26,65\%, СТ-41,76\%. При этом в первой группе был следующей распределение аллелей и генотипов: аллеля С и Т были обнаружены в соотношении $46,67 \%$ к 53,93\%, генотипы СС-32,00\%, ТТ-28,00\%, СТ 40, 00\%, во II группе аллели - С$51,56 \%$, T - 48,44\%, генотипы - СС 28,13\%, ТТ-25,00\%, СТ 46,88\%, в III группе - аллель С достоверно чаще регистрировалась, чем Т $(68,00 \%$ против $32,00 \%, \mathrm{p}<0,05)$ и генотип TT - чаще, чем СС и СТ (52,00\% против 16,00\% и 32,00\%). В IV (контрольной) группе был такой распределение частоты аллелей и генотипов полиморфизма гена: аллель С- 
40,00\%, аллель Т 60,00\%, генотип СС 38,71\%, генотип ТТ - 19,35\%, генотип СТ 41,93\%. Самые низкие ежемесячные показатели массы тела и ее прироста ассоциировались с генотипом ТT гена ACTN3 (rs1815739) у недоношенных детей и детей со ЗВУР в первом полугодии, а среди детей группы сравнения - во втором полугодии, однако общие показатели прироста массы тела за 12 месяцев генотиповой зависимости. Преждевременно рожденные дети (I и II группы наблюдения) с генотипом ТT гена ACTN3 (rs1815739) имели неравномерно меньшие показатели длины тела в течение первого года жизни, в то время как дети со ЗВУР отставали в своем росте в первом, а дети из группы контроля - в втором полугодии. Общий годовой прирост длины тела за первый год жизни у всех детей с генотипом ТТ, был самым низким и составил в первой группе - 28,50 $\pm 1,03 \mathrm{~cm}$, во II $-24,03 \pm 0,93 \mathrm{~cm}$, в III $-25,50 \pm$ $1,04 \mathrm{~cm}$, в IV - 23,00 \pm 0,98cм. Установлена достоверная положительная корреляционная зависимость между продолжительностью естественного вскармливания и ежемесячным приростом длины тела у детей с генотипом ТТ гена ACTN3 (rs1815739): $\gamma=0,58, \gamma=$ 0,76, $\gamma=0,61$ с I, II и III групп наблюдения соответственно.

Выводы. Установлено, что генотип ТT гена ACTN3 (rs1815739) у детей ассоциируется с их неравномерным физическим развитием на первом году жизни и достоверно меньшими показателями прироста длины тела за 12 месяцев, а продолжительное естественное вскармливание, особенно недоношенных детей и детей с задержкой внутриутробного развития, будет способствовать их нормальному росту.

Ключевые слова: дети; физическое развитие; масса тела; длина; полиморфизм; генотип

Introduction. Impaired physical development of children born with low birth weight is an urgent problem around the world, because the optimal rate of increase in their weight, body length, head circumference ensure normal physical development during their life later on. If the child does not increase body length/height, does not gain weight in accordance with the established genetic program of development, then there is no adequate increase in brain mass, which can negatively affect intellectual development. Early child development is considered one of the most important stages of life, which determines health, well-being, ability to learn, and behavior throughout life [1]. Today, the World Health Organization (WHO) identifies physical development as one of the fundamental criteria in a comprehensive assessment of a child's health. Therefore, the factors influencing the rate of physical development of premature infants require further study [2]. 
According to the modern understanding of genetics, the peculiarities of physical development are due to DNA polymorphisms, of which there are more than 17 million. More than 214 genes are now known, the polymorphisms of which are associated with the development and manifestation of human physical qualities. ACTN3 is a gene that encodes $\alpha-$ actinin-3, a protein expressed only in type II muscle fibers. It is well known that skeletal muscle is made up of individual muscle fibers, which are classified as slow-type fibers (type I fibers) and fast-type fibers (type II fibers). Type I fibers are more effective at using oxygen to produce ATP, which affects the ability to perform resilience and endurance exercises, such as marathons or cycling. The work of type II fibers requires a lot of energy, but the way to get it is under anaerobic conditions, which leads to low endurance of muscles, which in turn affects the quality of muscle tissue as a whole. A common polymorphism of this gene is R577X (rs1815739), where the replacement of $\mathrm{C}$ by $\mathrm{T}$ alleles results in the conversion of the arginine base $(\mathrm{R})$ to a premature stop codon $(\mathrm{X})$. According to the analysis, $\mathrm{X}$-allelic homozygotes have a deficiency of the protein $\alpha$-actinin-3, which is associated with a lower percentage of rapid fiber contraction. In most studies, the ACTN3 genotype is associated with the phenotypes of speed and power, which affect the quality of muscle tissue. However, there are a small number of studies linking the effect of ACTN3 C / T gene polymorphism (rs1815739) on motor activity, density, and bone growth. [3, 4, 5]

Materials and methods. To study the C/T polymorphism of the ACTN3 gene (rs1815739), 170 newborns were examined. Newborns were divided into 4 groups depending on birth weight: Group I - 50 premature babies weighing 1500-1999 grams (1776.26 20.06 grams), Group II - 64 premature babies with birth weight 2000-2499 grams (2225.31 \pm 19.46 grams), group III - 25 children with normal gestational age at birth, but with intrauterine growth retardation $(2105.00 \pm 56,41)$, group IV (control group) - 31 children with normal gestational age and birth weight more than 2500 grams (3009.03 \pm 73.04 grams). Genotyping was performed by polymerase chain reaction according to the instructions (Applied Biosystems, USA) using total DNA samples isolated from whole venous blood using a set of reagents "SNP-Screen" (manufactured by "Syntol") on the CFXteTM Real-Time PCR amplifier (Bio-Rad Laboratories, Inc., USA). This study was conducted in the Department of Molecular Genetic Research of the Training Medical and Laboratory Center at the Department of Microbiology, Zaporizhzhia State Medical University, Zaporizhzhia. The work was carried out within the framework of the research department of the Children Diseases Department of Zaporizhzhia State Medical University 114U001397. 
The results of the distribution of allele frequencies and genotypes of the studied gene took into account the analysis of the genetic structure of the population according to HardyWeinberg's law. To compare the frequencies of alleles and genotypes in different groups a nonparametric statistical method " $2 \times 2$ Table", the Chi-square $(\mathrm{df}=1)$ was used. We also calculated the odds ratio (OR) using a four-point table with the calculation of the confidence interval (CI) by the Woolf method. The correlation between the indicators was performed by the Spearman method $\mathrm{r}_{\mathrm{s}}$ or Gamma $(\gamma)$.

Non-parametric statistics methods of the licensed software package Statistica for Windows 13 were used to process the results of the study.

The work aims at studying the prevalence and influence of polymorphism of the $\mathrm{C} / \mathrm{T}$ gene polymorphism of ACTN3 gene (rs1815739) on the physical development of children born with low body weight.

Results. Molecular genetic study of CT polymorphism of the ACTN3 gene (rs1815739) in all studied children showed that the frequency of detection of the $\mathrm{C}$ allele was $51.47 \%$, the T allele $-48.52 \%$, the frequency of occurrence of genotypes SS-30.59\%, TT-26, $65 \%$, CT-41.76\%. In group I there was the following distribution of alleles and genotypes: alleles $\mathrm{C}$ and $\mathrm{T}$ were detected in the ratio of $46.67 \%$ to $53.93 \%$, genotypes SS-32.00\%, TT$28.00 \%$, CT-40.00\%, in group II alleles - C-51.56\%, T - 48.44\%, genotypes CC 28.13\%, TT$25,00 \%$, CT $-46,88 \%$, in group III - allele C was significantly more often registered, than T (32.00\% vs. $68.00 \%$, p <0.05), genotypes - CC- $16.00 \%$, TT-52.00\%, CT-32.00\%. The control group had the following distribution of the frequency of alleles and genotypes of gene polymorphism: allele $\mathrm{C}-40.00 \%$, allele $\mathrm{T}-60.00 \%$, genotype CC $-38.71 \%$, genotype TT $19.35 \%$, genotype CT-41.93\%. These data are clearly presented in fig. 1 and in table 1.

Analyzing the data in Table 1, we can conclude that the CC genotype is significantly less common in children of group III who had intrauterine growth retardation than among children of groups I, II, and IV ( $\mathrm{p}<0.05)$. The TT genotype is significantly less common among children weighing more than $2500 \mathrm{~g}(\mathrm{p}<0.05)$ than among children in other groups. Heterozygous type of CT was significantly more common among children of group II than among children of group I and children of group III - significantly less common than among children of groups I, II, and IV.

Further in our study, we decided to estimate body weight, body length, and weight gain and body length monthly in the first year of life, depending on the genotype of the polymorphism of the C/T polymorphism gene of the ACTN3 gene (rs1815739). These data are shown in tables 2-11. 


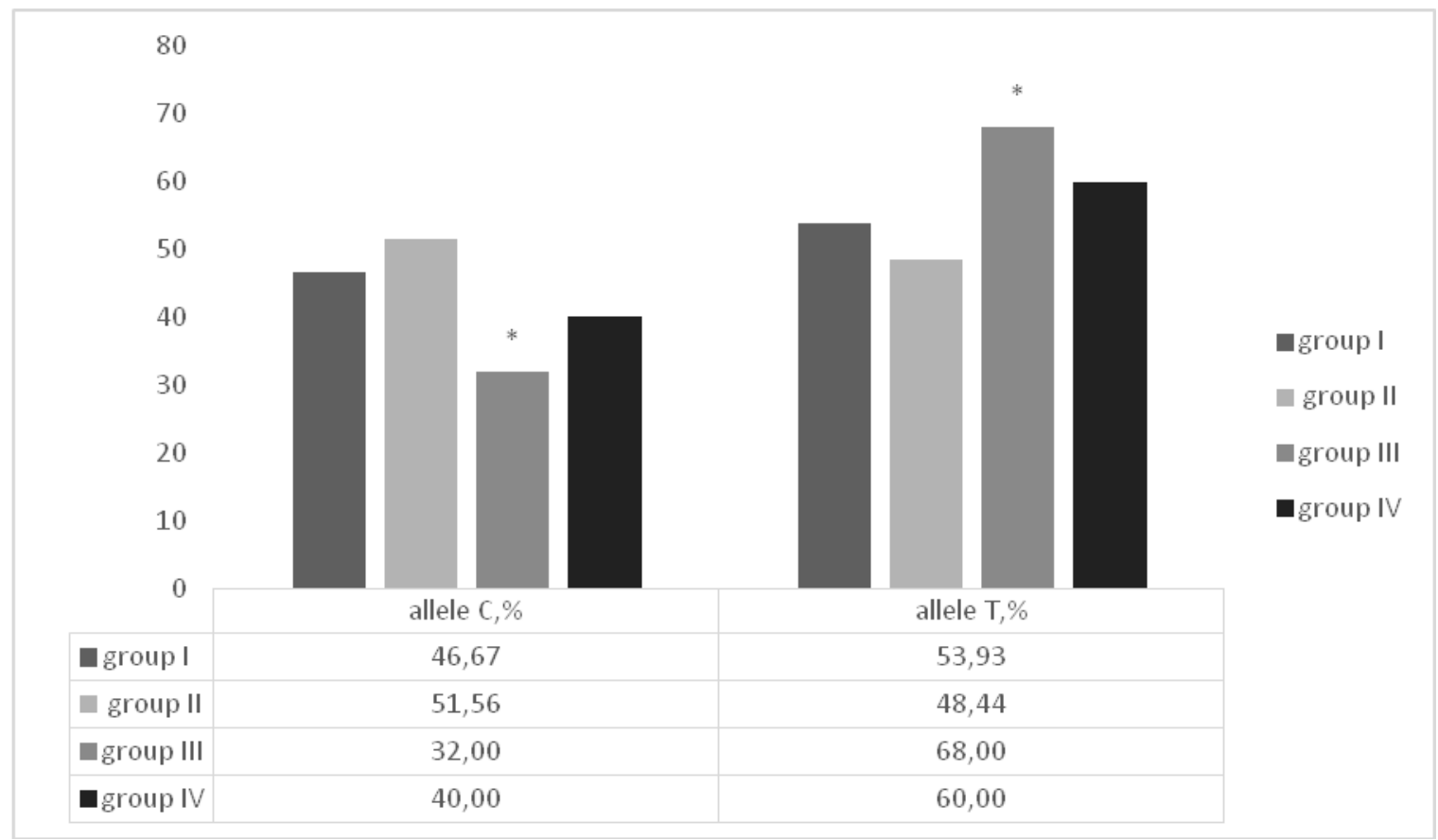

Fig.1. Frequency of alleles of polymorphism of the gene of polymorphism of C/T of the ACTN3 gene (rs1815739)

$* \mathrm{p}<0.05$

Table 1. Characterization of genotypes of the ACTN3 gene (rs1107946) polymorphism (abs./\%)

\begin{tabular}{|c|c|c|c|c|}
\hline \multirow[t]{2}{*}{ Groups } & \multirow[t]{2}{*}{$\mathrm{n}$} & \multicolumn{3}{|c|}{ Genotype abs/\% } \\
\hline & & $\mathrm{CC}$ & TT & CT \\
\hline Group I & 50 & $16 / 32.00 \%$ & $14 / 28.00 \%$ & $20 / 40.00 \%$ \\
\hline Group II & 64 & $18 / 28.13 \%$ & $16 / 25.00 \%$ & $30 / 46.88 \%$ \\
\hline p I-II & & $\mathrm{p}<0.05$ & $\mathrm{p}<0.05$ & $\mathrm{p}<0.05$ \\
\hline Group III & 25 & $4 / 24.00 \%$ & $13 / 44.00 \%$ & $8 / 32.00 \%$ \\
\hline p I-III & & $\mathrm{p}>0.05$ & $\mathrm{p}<0.05$ & $p>0.05$ \\
\hline p II-III & & $p>0.05$ & $\mathrm{p}<0.05$ & $p>0.05$ \\
\hline Group IV & 31 & $12 / 38.71 \%$ & $6 / 19.35 \%$ & $13 / 41.93 \%$ \\
\hline p I- IV & & $p>0.05$ & $\mathrm{p}<0.05$ & $\mathrm{p}>0.05$ \\
\hline p II- IV & & $\mathrm{p}>0.05$ & $\mathrm{p}<0.05$ & $\mathrm{p}<0.05$ \\
\hline p III- IV & & $\mathrm{p}<0.05$ & $\mathrm{p}<0.05$ & $\mathrm{p}>0.05$ \\
\hline
\end{tabular}


Table 2. Dynamics of weight and weight gain in children of group I in the first year of life, depending on the genotype of the C/T polymorphism of the ACTN3 gene (rs1815739)

\begin{tabular}{|c|c|c|c|}
\hline $\begin{array}{l}\text { Age and increase per } \\
\text { month }\end{array}$ & CC genotype & TT genotype & CT genotype \\
\hline 0 month (at birth) & $1885.00 \pm 151.28$ & $1740.00 \pm 130.89$ & $1750.00 \pm 132.29$ \\
\hline 1st month & $3033.33 \pm 199.56$ & $2784.23 \pm 167.34$ & $3135.24 \pm 206.78$ \\
\hline Increase in 1 month & $1225.08 \pm 168.61 *$ & $1065.02 \pm 206.37^{*, * *}$ & $1356.43 \pm 156.23^{* * *}$ \\
\hline 2nd month & $4380.34 \pm 699.28$ & $3678.45 \pm 622.42$ & $4180.00 \pm 592.38$ \\
\hline Increase in 2 month & $950.45 \pm 367.25 *$ & $880.45 \pm 623.08^{*, * *}$ & $896.45 \pm 53.91^{* *}$ \\
\hline 3rd month & $5234012 \pm 189.05^{*}$ & $4965.32 \pm 236.05^{*}$ & $5010.78 \pm 236.05$ \\
\hline Increase in 3 month & $1106.00 \pm 402.23^{*}$ & $756.91 \pm 356.12^{*, * *}$ & $1045.23 \pm 345.45^{*:}$ \\
\hline 4th month & $5620.40 \pm 602.01$ & $5340.84 \pm 502.10$ & $5735.34 \pm 467.23$ \\
\hline Increase in 4 month & $492.00 \pm 136.27$ & $456.24 \pm 103.18$ & $501.34 \pm 161.82$ \\
\hline 5th month & $6360.67 \pm 737.11$ & $5930.24 \pm 534.23$ & $6245.91 \pm 430.26$ \\
\hline Increase in 5 month & $605.00 \pm 68.07$ & $405.00 \pm 103.24$ & $562.81 \pm 87.57$ \\
\hline 6th month & $6530.00 \pm 389.87 *$ & $6235.83 \pm 289.34^{*, * *}$ & $6635.50 \pm 367.20^{* *}$ \\
\hline Increase in 6 month & $570.00 \pm 87.47$ & $378.23 \pm 102.34$ & $510.30 \pm 99.23$ \\
\hline 7th month & $6795.00 \pm 190.53$ & $6500.67 \pm 184.94$ & $6812.31 \pm 170.28$ \\
\hline Increase in 7 month & $222.00 \pm 76.94$ & $150.32 \pm 90.43$ & $231.08 \pm 69.34$ \\
\hline 8th month & $7585.00 \pm 771.56$ & $6925.12 \pm 345.12$ & $7430.80 \pm 556.17$ \\
\hline Increase in 8 month & $430.00 \pm 28.28$ & $217.20 \pm 78.12$ & $405.34 \pm 61.38$ \\
\hline 9 th month & $7835.00 \pm 305.51$ & $7325.12 \pm 207.18$ & $7925.50 \pm 290.34$ \\
\hline Increase in 9 month & $362.50 \pm 53.03$ & $324.45 \pm 62.87$ & $330.12 \pm 63.81$ \\
\hline 10th month & $8205.33 \pm 432.47$ & $7785.91 \pm 322.71$ & $8305.50 \pm 398.98$ \\
\hline Increase in 10 month & $350.00 \pm 45.64$ & $205.35 \pm 96.91$ & $300.01 \pm 51.98$ \\
\hline 11th month & $8490.50 \pm 538.23$ & $8230.50 \pm 431.81$ & $8360.45 \pm 502.87$ \\
\hline Increase in 11 month & $162.50 \pm 47.87$ & $150.54 \pm 76.23$ & $195.50 \pm 59.94$ \\
\hline 12 month & $8950.00 \pm 1184.62$ & $8435.50 \pm 352.23$ & $8755.98 \pm 962.35$ \\
\hline Increase in 12 month & $97.50 \pm 31.67$ & $85.50 \pm 41.13$ & $105.50 \pm 53.23$ \\
\hline $\begin{array}{l}\text { Weight gain overall } 12 \\
\text { months }\end{array}$ & $7435.00 \pm 165.87$ & $6755.00 \pm 334.98$ & $7356.50 \pm 198.56$ \\
\hline
\end{tabular}

$* \mathrm{P}<0.05$ significant difference between children of group I with genotype CC and TT $* * \mathrm{P}<0.05$ significant difference between children of group I with genotype CT and TT.

Children of group I with the TT genotype had a significantly lower weight at the age of 3.6 months compared with children with the SS genotype $(\mathrm{p}<0.05)$ and at the age of 6 months - with the CT genotype ( $\mathrm{p}$ <.05). Regarding the monthly weight gain, it was found that in this observation group, children with the TT genotype had a significantly lower weight gain at 1,2, 3, 6 months than children with the CC and CT genotypes ( $\mathrm{p}<0.05$ ). But at 12 months of age, both mean body weight and total annual gain did not depend on the genotype of the ACTN3 gene polymorphism (rs1815739). 
Among children of group II, significantly lower weight was found among children with TT genotype at the age of 1 and 2 months compared with children with CC genotype (p $<0.05)$. No significant difference with heterozygotes was found (table 3).

Table 3. Dynamics of weight and weight gain in children of group II in the first year of life, depending on the C/T polymorphism of the ACTN3 gene (rs1815739)

\begin{tabular}{|l|c|c|c|}
\hline Age and increase per month & CC genotype & TT genotype & CT genotype \\
\hline 0 month (at birth) & $2210.40 \pm 181.59$ & $2225.50 \pm 151.92$ & $2230.60 \pm 146.06$ \\
\hline 1st month & $3650.02 \pm 234.23 *$ & $3150.00 \pm 212.13 *$ & $3450.08 \pm 251.20$ \\
\hline Increase in 1 month & $1330.00 \pm 190.20$ & $1130.00 \pm 160.76$ & $1410.25 \pm 200.82$ \\
\hline 2nd month & $4987.67 \pm 518.07 *$ & $4616.67 \pm 417.33 *$ & $4863.67 \pm 534.37$ \\
\hline Increase in 2 month & $1083.33 \pm 329.64$ & $983.56 \pm 221.54$ & $1057.23 \pm 345.44$ \\
\hline 3rd month & $5432.06 \pm 465.43$ & $5125.00 \pm 365.47$ & $5253.43 \pm 474.33$ \\
\hline Increase in 3 month & $501.25 \pm 103.45$ & $422.50 \pm 208.38$ & $462.33 \pm 231.45$ \\
\hline 4th month & $5956.11 \pm 523.08$ & $5350.00 \pm 414.34$ & $5750.23 \pm 516.73$ \\
\hline Increase in 4 month & $720.34 \pm 251.09$ & $662.51 \pm 231.07$ & $689.49 \pm 211.12$ \\
\hline 5th month & $6275.39 \pm 245.92$ & $5934.34 \pm 204.11$ & $6175.59 \pm 265.16$ \\
\hline Increase in 5 month & $389.20 \pm 93.21$ & $350.00 \pm 84.52$ & $402.23 \pm 76.54$ \\
\hline 6th month & $6553.00 \pm 267.31$ & $6350.00 \pm 342.26$ & $6710.30 \pm 300.18$ \\
\hline Increase in 6 month & $352.46 \pm 102.83$ & $292.86 \pm 142.68$ & $286.18 \pm 155.85$ \\
\hline 7th month & $7123.49 \pm 242.14$ & $6950.00 \pm 342.26$ & $7215.01 \pm 290.61$ \\
\hline Increase in 7 month & $398.00 \pm 129.58$ & $400.00 \pm 209.31$ & $420.01 \pm 229.45$ \\
\hline 8th month & $7532.10 \pm 143.85$ & $7330.00 \pm 263.63$ & $7623.82 \pm 143.27$ \\
\hline Increase in 8 month & $230.87 \pm 65.34$ & $120.00 \pm 57.01$ & $255.67 \pm 58.88$ \\
\hline 9th month & $7765.00 \pm 273.86$ & $7450.00 \pm 263.56$ & $7672.02 \pm 232.13$ \\
\hline Increase in 9 month & $211.26 \pm 69.34$ & $208.33 \pm 73.60$ & $230.33 \pm 59.80$ \\
\hline 10th month & $8156.73 \pm 234.52$ & $7666.67 \pm 273.25$ & $7866.67 \pm 205.31$ \\
\hline Increase in 10 month & $178.44 \pm 58.10$ & $166.67 \pm 93.09$ & $156.35 \pm 67.23$ \\
\hline 11th month & $8542.39 \pm 306.17$ & $8441.67 \pm 352.73$ & $8601.70 \pm 302.22$ \\
\hline Increase in 11 month & $190.30 \pm 31.82$ & $165.00 \pm 41.83$ & $205.33 \pm 45.33$ \\
\hline 12 month & $9134.45 \pm 298.45$ & $9016.67 \pm 365.61$ & $9221.34 \pm 321.11$ \\
\hline Increase in 12 month & $103 \pm 45.32$ & $91.67 \pm 58.45$ & $120 \pm 36.82$ \\
\hline $\begin{array}{l}\text { Weight gain overall } 12 \\
\text { months }\end{array}$ & $7345.00 \pm 152.12$ & $6967.5 \pm 212.89$ & $7348.00 \pm 356.67$ \\
\hline P 0.05 signifant & & & \\
\hline
\end{tabular}

* $\mathrm{P}<0.05$ significant difference between children of group II with genotype CC and TT ** $\mathrm{P}<0.05$ significant difference between children of group II with genotype CT and TT

Children from the third observation group, who were born with intrauterine growth retardation and genotype TT, had a significantly lower birth weight compared with children with genotype CC and CT ( $\mathrm{p}<0.05)$. Also, children with the TT genotype had a significantly lower weight at the age of 1, 2, and 3 months compared with children with the dominant CC genotype ( $\mathrm{p}$ <0.05). No significant difference with heterozygotes was found (table 4$)$. At the same time, weight gain among children of group III depending on CT polymorphism of the 
ACTN3 gene (rs1815739) was significantly lower in children with minor genotype compared to children with major genotype at 3,5 , and 8 months $(\mathrm{p}<0.05)$. A significant difference between children with the TT and CT genotype was found only at the age of 5 months (p $<0.05)$.

Table 4. Dynamics of weight and body weight gain in children of group III in the first year of life, depending on the C/T polymorphism of the ACTN3 gene (rs1815739)

\begin{tabular}{|l|c|c|c|}
\hline \multicolumn{1}{|c|}{$\begin{array}{c}\text { Age and increase per } \\
\text { month }\end{array}$} & CC genotype & TT genotype & CT genotype \\
\hline 0 month (at birth) & $2310.00 \pm 143.03^{*}$ & $1860.00 \pm 353.71^{* * *}$ & $2070.00 \pm 156.34^{* *}$ \\
\hline 1st month & $3130.00 \pm 506.38^{*}$ & $2890.00 \pm 276.08^{*}$ & $3350.00 \pm 395.29$ \\
\hline Increase in 1 month & $890.00 \pm 433.73$ & $525.00 \pm 151.71$ & $1000.00 \pm 360.41$ \\
\hline 2nd month & $4130.86 \pm 711.68^{*}$ & $3760.00 \pm 415.93^{*}$ & $4247.5 \pm 289.87$ \\
\hline Increase in 2 month & $1070.00 \pm 422.20$ & $580.00 \pm 83.67$ & $1202.50 \pm 468.40$ \\
\hline 3rd month & $4970.00 \pm 223.50^{*}$ & $4300 \pm 380.79^{*}$ & $5242.86 \pm 430.53$ \\
\hline Increase in 3 month & $1000.00 \pm 223.50^{*}$ & $400.00 \pm 236.1^{*}$ & $915.00 \pm 247.45$ \\
\hline 4th month & $5325.00 \pm 817.91$ & $5750.00 \pm 516.85$ & $6000.00 \pm 424.26$ \\
\hline Increase in 4 month & $600.00 \pm 339.75$ & $550.00 \pm 178.89$ & $966.67 \pm 202.07$ \\
\hline 5th month & $6000.00 \pm 1378.22$ & $6500.00 \pm 368.21$ & $6470.00 \pm 1266.33$ \\
\hline Increase in 5 month & $670.00 \pm 167.09^{*}$ & $450.00 \pm 74.36^{* * * *}$ & $682.50 \pm 170.49 * *$ \\
\hline 6th month & $6650.00 \pm 1240.03$ & $7000.00 \pm 377.52$ & $7398.33 \pm 917.39$ \\
\hline Increase in 6 month & $550.00 \pm 154.97$ & $430 \pm 127.95$ & $650.00 \pm 150.00$ \\
\hline 7th month & $7400.00 \pm 1343.50$ & $7400.00 \pm 325.19$ & $7604.00 \pm 766.05$ \\
\hline Increase in 7 month & $400.00 \pm 160.56$ & $400 \pm 157.89$ & $440.00 \pm 152.49$ \\
\hline 8th month & $7850.00 \pm 1325.03$ & $7850.00 \pm 724.22$ & $8100.00 \pm 787.40$ \\
\hline Increase in 8 month & $500.00 \pm 72.23^{*}$ & $300 \pm 57.01^{*}$ & $460.00 \pm 69.797$ \\
\hline 9th month & $8400.00 \pm 1398.03$ & $8347.50 \pm 406.10$ & $8700.00 \pm 921.61$ \\
\hline Increase in 9 month & $420.00 \pm 124.50$ & $340 \pm 58.99$ & $512.00 \pm 103.68$ \\
\hline 10th month & $8950.00 \pm 1501.77$ & $8737.50 \pm 300.83$ & $9300.00 \pm 1035.52$ \\
\hline Increase in 10 month & $300.00 \pm 65.19$ & $250 \pm 111.22$ & $380.00 \pm 88.531$ \\
\hline 11th month & $9500.00 \pm 1123.56$ & $9460.00 \pm 188.41$ & $9800.00 \pm 1143.68$ \\
\hline Increase in 11 month & $250.00 \pm 86.41$ & $200 \pm 108.39$ & $230.00 \pm 79.34$ \\
\hline 12 month & $10100.00 \pm 913.05$ & $9160.00 \pm 173.26$ & $10000.00 \pm 1171.75$ \\
\hline Increase in 12 month & $225.00 \pm 52.44$ & $200 \pm 109.75$ & $220.00 \pm 35.09$ \\
\hline $\begin{array}{l}\text { Weight gain overall 12 } \\
\text { months }\end{array}$ & $7155.00 \pm 555.00$ & $6943.33 \pm 365.49$ & $7246.25 \pm 301.75$ \\
\hline
\end{tabular}

* $\mathrm{P}<0.05$ significant difference between children of group III with genotype CC and TT $* * \mathrm{P}<0.05$ significant difference between children of group III with genotype CT and TT

Among children of control group IV, the effect of C/T polymorphism of the ACTN3 gene (rs1815739) on weight and its monthly increase was detected in the second half of the year, namely, children with homozygous recessive TT genotype had significantly lower weight and weight gain compared to children with $\mathrm{CC}$ genotype and at the age of 10,11 and 
12 months ( $\mathrm{p}<0.05)$. There was no significant difference between weight and monthly gain among children with CC and CT genotypes (Table 5).

Table 5. Dynamics of weight and body weight gain in children of group IV in the first year of life, depending on the C/T polymorphism of the ACTN3 gene (rs1815739)

\begin{tabular}{|l|l|l|l|}
\hline $\begin{array}{l}\text { Age and increase per } \\
\text { month }\end{array}$ & CC genotype & TT genotype & CT genotype \\
\hline 0 month (at birth) & $2945.00 \pm 417.75$ & $3195.00 \pm 512.77$ & $2790.00 \pm 334.47$ \\
\hline 1st month & $3725.00 \pm 198.34$ & $3565.06 \pm 156.43$ & $3680.54 \pm 205.12$ \\
\hline Increase in 1 month & $987.54 \pm 48.13$ & $950.26 \pm 52.01$ & $1001.03 \pm 56.50$ \\
\hline 2nd month & $4650.06 \pm 134.56$ & $4430.00 \pm 127.86$ & $4675.93 \pm 131.05$ \\
\hline Increase in 2 month & $765.98 \pm 67.23$ & $754.03 \pm 56.06$ & $788.01 \pm 63.09$ \\
\hline 3rd month & $5425.73 \pm 187.45$ & $5260.98 \pm 204.12$ & $5335.06 \pm 198.34$ \\
\hline Increase in 3 month & $664.83 \pm 70.01$ & $634.72 \pm 65.23$ & $652.01 \pm 91$ \\
\hline 4th month & $6100.65 \pm 187.23$ & $5985.12 \pm 186.45$ & $6050.56 \pm 178.23$ \\
\hline Increase in 4 month & $599.34+56.23$ & $584.98 \pm 34.09$ & $607.98 \pm 57.12$ \\
\hline 5th month & $6720.04 \pm 198.56$ & $6550.34 \pm 178.56$ & $6660.34 \pm 182.36$ \\
\hline Increase in 5 month & $510.11 \pm 45.78$ & $487.12 \pm 51.12$ & $513.05 \pm 43.12$ \\
\hline 6th month & $7345.23 \pm 220.62$ & $7125.78 \pm 189.34$ & $7230.34 \pm 91.97$ \\
\hline Increase in 6 month & $420.16 \pm 71.23$ & $398.12 \pm 54.98$ & $412.34 \pm 81.01$ \\
\hline 7 th month & $8125.20 \pm 234.56$ & $7890.65 \pm 256.10$ & $8090.41 \pm 54$ \\
\hline Increase in 7 month & $390.12 \pm 67.23$ & $325.67 \pm 39$ & $376.24 \pm 28.65$ \\
\hline 8th month & $8765.93 \pm 233.45$ & $8345.24 \pm 212$ & $8450.25 \pm 234.56$ \\
\hline Increase in 8 month & $467.24 \pm 63.29$ & $367.91 \pm 78.34$ & $478.29 \pm 39.23$ \\
\hline 9th month & $9010.32 \pm 245.73$ & $8765.12 \pm 203.34$ & $8995.23 \pm 225.65$ \\
\hline Increase in 9 month & $427.23 \pm 88.09$ & $350.73 \pm 76.22$ & $456.23 \pm 83$ \\
\hline 10th month & $9355.27 \pm 301.48^{*}$ & $9020.09 \pm 201.38^{*}, * *$ & $9650.87 \pm 290.29 * *$ \\
\hline Increase in 10 month & $389.12 \pm 131.39^{*}$ & $290.13 \pm 102.34 * * *$ & $406.39 \pm 102.41^{* *}$ \\
\hline 11th month & $10010.34 \pm 387.23^{*}$ & $9450.98 \pm 302.83^{*}, * *$ & $9990.45 \pm 342.71 * *$ \\
\hline Increase in 11 month & $561.23 \pm 152.56^{*}$ & $351.03 \pm 87.34^{*}, * *$ & $490.34 \pm 122.34 * *$ \\
\hline 12 month & $10705.43 \pm 257.56^{*}$ & $9955.98 \pm 189.90^{*}, * *$ & $10565.65 \pm 234.65^{* *}$ \\
\hline Increase in 12 month & $243.89 \pm 98.45^{*}$ & $150.98 \pm 34.43^{*}, * *$ & $234.51 \pm 87.54 * *$ \\
\hline $\begin{array}{l}\text { Weight gain overall } \\
\text { 12 months }\end{array}$ & $7896.50 \pm 214.76$ & $7345.00 \pm 256.89$ & $7689.00 \pm 234.62$ \\
\hline
\end{tabular}

$* \mathrm{P}<0.05$ significant difference between children of group IV with genotype CC and TT $* * \mathrm{P}<0.05$ significant difference between children of group IV with genotype CT and TT

Based on the data in table 6 , we can conclude that body length was significantly shorter in children with the TT genotype compared with the CC genotype at birth and 1 month of age. With further growth of the child, both the indicators of the dynamics of body length and its monthly growth were lower in children with the TT genotype, compared with the other two genotypes, at the age of $3,4,5,6,7$, and 8 months $(p<0,05)$. 
Table 6. Dynamics of body length and its monthly growth in children of group I in the first year of life, depending on the C/T polymorphism of the ACTN3 gene (rs1815739)

\begin{tabular}{|l|c|c|c|}
\hline Age and increase per month & CC genotype & TT genotype & CT genotype \\
\hline 0 month (at birth) & $42.90 \pm 1.02^{*}$ & $41.75 \pm 2.25^{*}$ & $41.10 \pm 1.75$ \\
\hline 1st month & $45.50 \pm 1.22^{*}$ & $42.90 \pm 2.49^{*}$ & $43.40 \pm 1.52$ \\
\hline Increase in 1 month & $3.10 \pm 0.22$ & $3.06 \pm 1.37$ & $2.70 \pm 0.45$ \\
\hline 2nd month & $49.40 \pm 17.63$ & $50.67 \pm 3.72$ & $46.60 \pm 1.95$ \\
\hline Increase in 2 month & $3.40 \pm 0.96$ & $2.58 \pm 0.49$ & $3.60 \pm 1.14$ \\
\hline 3rd month & $53.60 \pm 3.77^{*}$ & $48.20 \pm 1.52^{*}$ & $49.60 \pm 1.52$ \\
\hline Increase in 3 month & $3.40 \pm 0.55$ & $2.80 \pm 0.84$ & $3.70 \pm 0.71$ \\
\hline 4th month & $54.20 \pm 1.30^{*}$ & $50.40 \pm 2.70^{*}, * *$ & $53.40 \pm 1.52^{* *}$ \\
\hline Increase in 4 month & $3.80 \pm 0.45^{*}$ & $1.60 \pm 0.89^{*}, * *$ & $3.80 \pm 0.44^{* *}$ \\
\hline 5th month & $57.60 \pm 0.89^{*}$ & $53.25 \pm 1.5 * * *$ & $56.80 \pm 1.48^{* *}$ \\
\hline Increase in 5 month & $3.00 \pm 0.71^{*}$ & $1.70 \pm 0.45^{*}$ & $2.80 \pm 0.84$ \\
\hline 6th month & $59.83 \pm 1.83^{*}$ & $56.40 \pm 1.14^{*}, * *$ & $58.83 \pm 1.73^{* *}$ \\
\hline Increase in 6 month & $2.83 \pm 0.75^{*}$ & $1.60 \pm 0.89^{*}$ & $2.50 \pm 1.05$ \\
\hline 7 th month & $65.17 \pm 1.17^{*}$ & $61.67 \pm 1.16^{*}, * *$ & $62.60 \pm 1.95^{* *}$ \\
\hline Increase in 7 month & $3.00 \pm 0.71^{*}$ & $1.30 \pm 0.84^{*}, * *$ & $3.33 \pm 0.71^{* *}$ \\
\hline 8th month & $66.50 \pm 1.52^{*}$ & $62.50 \pm 2.38^{*}, * *$ & $65.20 \pm 1.48^{* *}$ \\
\hline Increase in 8 month & $2.67 \pm 0.82$ & $1.80 \pm 0.84$ & $2.40 \pm 0.55$ \\
\hline 9th month & $67.67 \pm 1.21$ & $66.40 \pm 2.79$ & $67.60 \pm 1.14$ \\
\hline Increase in 9 month & $2.67 \pm 0.52$ & $2.00 \pm 0.71$ & $2.60 \pm 0.55$ \\
\hline 10th month & $69.67 \pm 0.81$ & $70.50 \pm 0.71$ & $69.40 \pm 0.55$ \\
\hline Increase in 10 month & $2.00 \pm 0.89$ & $1.40 \pm 0.55$ & $1.60 \pm 0.89$ \\
\hline 11th month & $71.50 \pm 0.84$ & $70.80 \pm 1.64$ & $71.00 \pm 0.71$ \\
\hline Increase in 11 month & $2.00 \pm 0.63$ & $1.20 \pm 0.84$ & $1.80 \pm 0.45$ \\
\hline 12 month & $73.00 \pm 1.26$ & $72.75 \pm 2.36$ & $72.80 \pm 1.30$ \\
\hline Increase in 12 month & $1.83 \pm 0.75$ & $1.75 \pm 0.50$ & $1.80 \pm 0.84$ \\
\hline The average increase in body & $31.25 \pm 0.96^{*}$ & $28.50 \pm 1.03^{*}, * *$ & $30.50 \pm 0.89^{* *}$ \\
length over 12 months & & & \\
\hline
\end{tabular}

$* \mathrm{P}<0.05$ significant difference between children of group I with genotype $\mathrm{CC}$ and TT $* * \mathrm{P}<0.05$ significant difference between children of group I with genotype CT and TT

Regarding the characteristics of body length among children of group II, it was found that children with the TT genotype had significantly lower rates compared with children with the CC genotype at the age of $0,1,6,9$, and 12 months $(\mathrm{p}<0.05)$.

The effect of ACTN3 gene polymorphism (rs1815739) on body length and growth in children born with intrauterine growth retardation depending on genotype was detected mainly in the first half of the year. Thus, children with TT genotype had shorter body length than children with CC genotype at the age of 1, 2, and 3 months, CT and CT genotypes at 4.5 and 6 months ( $\mathrm{p}<0.05)$, and shorter length gain body was detected at the age of 1, 2, 3 and 4 months in children with genotypes TT and CC, at the age of 5 months - with genotypes TT and CT and CC (p <0,05) (table 8). 
Table 7. Dynamics of body length and its monthly growth in children of group II in the first year of life, depending on the C/T polymorphism of the ACTN3 gene (rs1815739)

\begin{tabular}{|l|c|c|c|}
\hline Age and increase per month & CC genotype & TT genotype & CT genotype \\
\hline 0 month (at birth) & $47.50 \pm 3.67^{*}$ & $43.75 \pm 1.71^{*}$ & $45.50 \pm 1.05$ \\
\hline 1st month & $50.83 \pm 2.79^{*}$ & $48.75 \pm 1.71^{*}$ & $49.35 \pm 0.75$ \\
\hline Increase in 1 month & $5.00 \pm 1.41$ & $4.25 \pm 1.26$ & $3.33 \pm 0.82$ \\
\hline 2nd month & $54.10 \pm 1.67$ & $52.00 \pm 3.16$ & $54.17 \pm 1.47$ \\
\hline Increase in 2 month & $5.00 \pm 1.45$ & $3.00 \pm 0.89$ & $3.33 \pm 1.21$ \\
\hline 3rd month & $58.20 \pm 1.64$ & $55.17 \pm 2.64$ & $57.17 \pm 1.72$ \\
\hline Increase in 3 month & $7.00 \pm 5.66$ & $2.67 \pm 0.82$ & $2.83 \pm 0.75$ \\
\hline 4th month & $59.80 \pm 1.30$ & $57.33 \pm 2.50$ & $59.17 \pm 2.23$ \\
\hline Increase in 4 month & $2.45 \pm 1.50$ & $2.83 \pm 0.75$ & $2.00 \pm 0.63$ \\
\hline 5th month & $62.50 \pm 1.91$ & $59.33 \pm 2.58$ & $62.00 \pm 1.89$ \\
\hline Increase in 5 month & $3.00 \pm 0.75$ & $2.25 \pm 0.61$ & $2.83 \pm 0.75$ \\
\hline 6th month & $65.67 \pm 1.53^{*}$ & $62.08 \pm 2.54^{*}$ & $63.50 \pm 2.26$ \\
\hline Increase in 6 month & $1.76 \pm 0.93$ & $2.08 \pm 0.49$ & $1.67 \pm 0.82$ \\
\hline 7 th month & $66.60 \pm 3.58$ & $63.00 \pm 1.41$ & $65.50 \pm 2.43$ \\
\hline Increase in 7 month & $2.00 \pm 0.76$ & $2.17 \pm 0.52$ & $2.00 \pm 0.89$ \\
\hline 8th month & $68.83 \pm 2.57^{*}$ & $64.83 \pm 1.47^{*} * *$ & $67.83 \pm 2.26 * *$ \\
\hline Increase in 8 month & $2.00 \pm 0.68$ & $2.00 \pm 1.26$ & $2.33 \pm 0.41$ \\
\hline 9th month & $69.42 \pm 1.96^{*}$ & $66.00 \pm 1.26^{*}$ & $67.75 \pm 1.89$ \\
\hline Increase in 9 month & $1.15 \pm 0.50$ & $1.17 \pm 0.75$ & $1.58 \pm 0.38$ \\
\hline 10th month & $70.58 \pm 1.86^{*}$ & $68.00 \pm 1.79^{*}$ & $67.50 \pm 3.54$ \\
\hline Increase in 10 month & $2.35 \pm 0.45$ & $2.00 \pm 0.89$ & $1.17 \pm 0.26$ \\
\hline 11th month & $73.00 \pm 1.96^{*}$ & $69.50 \pm 1.87^{*}, * *$ & $71.83 \pm 1.72^{* *}$ \\
\hline Increase in 11 month & $1.76 \pm 0.48$ & $1.33 \pm 0.52$ & $1.53 \pm 0.32$ \\
\hline 12 month & $75.50 \pm 2.89^{*}$ & $71.33 \pm 1.37^{*}$ & $73.17 \pm 1.60$ \\
\hline Increase in 12 month & $3.67 \pm 1.00^{*}$ & $1.63 \pm 0.89^{*}$ & $1.75 \pm 1.05$ \\
\hline The average increase in body & $27.75 \pm 0.95^{*}$ & $24.03 \pm 0.93^{*}$ & $26.50 \pm 0.89$ \\
\hline length over 12 months & & & \\
\hline
\end{tabular}

$* \mathrm{P}<0.05$ significant difference between children of group II with genotype CC and TT ** $\mathrm{P}<0.05$ significant difference between children of group II with genotype CT and TT 
Table 8. Dynamics of body length and its monthly growth in children of group III in the first year of life, depending on the C/T polymorphism of the ACTN3 gene (rs1815739)

\begin{tabular}{|l|c|c|c|}
\hline Age and increase per month & CC genotype & TT genotype & CT genotype \\
\hline 0 month (at birth) & $47.43 \pm 1.62$ & $45.00 \pm 1.41$ & $47.25 \pm 1.83$ \\
\hline 1st month & $50.71 \pm 2.48^{*}$ & $45.33 \pm 2.52^{*}$ & $48.25 \pm 4.35$ \\
\hline Increase in 1 month & $3.38 \pm 2.40^{*}$ & $1.50 \pm 0.71^{*}$ & $2.7 \pm 0.67$ \\
\hline 2nd month & $55.25 \pm 1.89^{*}$ & $48.00 \pm 3.61^{*}$ & $54.50 \pm 2.06$ \\
\hline Increase in 2 month & $5.70 \pm 1.92^{*}$ & $2.33 \pm 1.53^{*}$ & $4.80 \pm 1.30$ \\
\hline 3rd month & $56.25 \pm 3.03^{*}$ & $50.33 \pm 4.16^{*}$ & $58.50 \pm 1.61$ \\
\hline Increase in 3 month & $2.75 \pm 0.50^{*}$ & $1.63 \pm 0.48^{*}$ & $3.60 \pm 2.22$ \\
\hline 4th month & $59.25 \pm 1.47^{*}$ & $53.25 \pm 5.32^{*}, *$ & $60.4 \pm 2.07^{*}, *$ \\
\hline Increase in 4 month & $3.5 \pm 1.95^{*}$ & $1.88 \pm 0.25^{*}$ & $2.60 \pm 0.82$ \\
\hline 5th month & $62.17 \pm 3.66^{*}$ & $54.13 \pm 5.45^{*}, * *$ & $64.50 \pm 1.29 *, * *$ \\
\hline Increase in 5 month & $2.92 \pm 1.90^{*}$ & $0.8 \pm 0.57 *, *$ & $3.75 \pm 0.96^{*}, * *$ \\
\hline 6th month & $63.00 \pm 2.45^{*}$ & $55.75 \pm 5.74^{*}, *$ & $66.40 \pm 2.41^{*}, * *$ \\
\hline Increase in 6 month & $2.30 \pm 1.10$ & $1.63 \pm 0.48$ & $2.60 \pm 0.89$ \\
\hline 7th month & $66.38 \pm 1.49$ & $59.00 \pm 7.87$ & $65.67 \pm 1.53$ \\
\hline Increase in 7 month & $2.13 \pm 1.65$ & $1.25 \pm 0.65$ & $2.00 \pm 1.00$ \\
\hline 8th month & $68.00 \pm 1.83$ & $63.00 \pm 6.56$ & $68.00 \pm 0.71$ \\
\hline Increase in 8 month & $2.00 \pm 0.82$ & $1.25 \pm 1.04$ & $2.38 \pm 0.75$ \\
\hline 9th month & $68.80 \pm 2.46$ & $65.00 \pm 5.57$ & $69.70 \pm 0.84$ \\
\hline Increase in 9 month & $2.20 \pm 1.35$ & $1.63 \pm 1.11$ & $1.63 \pm 0.45$ \\
\hline 10th month & $70.38 \pm 1.70$ & $65.5 \pm 5.07$ & $71.33 \pm 2.52$ \\
\hline Increase in 10 month & $2.50 \pm 1.29$ & $1.75 \pm 0.96$ & $1.7 \pm 0.84$ \\
\hline 11th month & $71.50 \pm 1.63$ & $66.88 \pm 5.36$ & $71.88 \pm 1.65$ \\
\hline Increase in 11 month & $2.60 \pm 1.14$ & $1.33 \pm 0.75$ & $1.63 \pm 0.48$ \\
\hline 12 month & $72.75 \pm 2.22$ & $69.75 \pm 4.57$ & $73.75 \pm 0.30$ \\
\hline Increase in 12 month & $1.60 \pm 0.55$ & $2.38 \pm 1.11$ & $2.00 \pm 1.41$ \\
\hline $\begin{array}{l}\text { The average increase in body } \\
\text { length over 12 months }\end{array}$ & $27.88 \pm 0.64^{*}$ & $25.50 \pm 1.04^{*}$ & $26.57 \pm 1.13$ \\
\hline
\end{tabular}

$* \mathrm{P}<0.05$ significant difference between children of group III with genotype CC and TT ** $\mathrm{P}<0.05$ significant difference between children of group III with genotype CT and TT 
Table 9. Dynamics of body length and its monthly growth in children of group IV in the first year of life, depending on the polymorphism of the C/T gene ACTN3 (rs1815739)

\begin{tabular}{|l|c|c|c|}
\hline Age and increase per month & CC genotype & TT genotype & CT genotype \\
\hline 0 month (at birth) & $53.45 \pm 0.78$ & $52.53 \pm 0.68$ & $52.07 \pm 0.75$ \\
\hline 1st month & $54.75 \pm 1.75$ & $53.05 \pm 1.33$ & $53.05 \pm 1.66$ \\
\hline Increase in 1 month & $2.24 \pm 0.92$ & $2.04 \pm 1.00$ & $2.50 \pm 1.05$ \\
\hline 2nd month & $58.50 \pm 1.50$ & $55.50 \pm 1.36$ & $57.50 \pm 0.98$ \\
\hline Increase in 2 month & $4.75 \pm 1.07$ & $4.35 \pm 0.87$ & $4.50 \pm 1.05$ \\
\hline 3rd month & $61.30 \pm 0.76$ & $60.07 \pm 1.01$ & $62.5 \pm 1.33$ \\
\hline Increase in 3 month & $2.35 \pm 0.85$ & $1.85 \pm 1.33$ & $2.05 \pm 0.68$ \\
\hline 4th month & $63.60 \pm 1.25$ & $61.55 \pm 1.50$ & $62.63 \pm 1.24$ \\
\hline Increase in 4 month & $2.5 \pm 0.50$ & $2.25 \pm 0.67$ & $2.01 \pm 0.89$ \\
\hline 5th month & $65.60 \pm 1.45$ & $64.55 \pm 1.05$ & $65.05 \pm 1.11$ \\
\hline Increase in 5 month & $1.5 \pm 0.51$ & $1.5 \pm 0.51$ & $1.5 \pm 0.51$ \\
\hline 6th month & $67.00 \pm 0.79$ & $66.05 \pm 1.25$ & $64.31 \pm 0.85$ \\
\hline Increase in 6 month & $2.50 \pm 0.45$ & $2.0 \pm 0.65$ & $2.0 \pm 1.00$ \\
\hline 7 th month & $68.56 \pm 0.67$ & $67.50- \pm 0.95$ & $66.05 \pm 1.01$ \\
\hline Increase in 7 month & $2.0 \pm 0.5$ & $2.05 \pm 0.45$ & $1.75 \pm 0.45$ \\
\hline 8th month & $69.05 \pm 1.75$ & $69.45 \pm 1.45$ & $68.65 \pm 1.05$ \\
\hline Increase in 8 month & $1.35 \pm 0.75$ & $1.05 \pm 0.56$ & $1.75 \pm 0.45$ \\
\hline 9th month & $70.5 \pm 0.97$ & $70.1 \pm 1.33$ & $70.3 \pm 0.95$ \\
\hline Increase in 9 month & $3.0 \pm 1.0$ & $2.50 \pm 1.05$ & $2.75 \pm 1.33$ \\
\hline 10th month & $73.45 \pm 1.85^{*}$ & $71.42 \pm 1.80^{*}, * *$ & $74.02 \pm 1.45^{* *}$ \\
\hline Increase in 10 month & $3.0 \pm 0.88^{*}$ & $2.0 \pm 0.45^{*}, * *$ & $2.33 \pm 0.75^{* *}$ \\
\hline 11th month & $74.5 \pm 2.65^{*}$ & $72.05 \pm 1.45^{*} * *$ & $75.03 \pm 2.55^{* *}$ \\
\hline Increase in 11 month & $1.75 \pm 0.95^{*}$ & $1.05 \pm 0.45^{*} * *$ & $1.50 \pm 0.53^{* *}$ \\
\hline 12 month & $76.0 \pm 0.95^{*}$ & $72.50 \pm 0.56^{*}, * *$ & $75.00 \pm 0.85^{* *}$ \\
\hline Increase in 12 month & $3.05 \pm 1.05^{*}$ & $1.5 \pm 1.04^{*}, * *$ & $2.75 \pm 0.98^{* *}$ \\
\hline The average increase in body & $25.67 \pm 0.79^{*}$ & $23.00 \pm 0.98^{*}, * *$ & $26.5 \pm 0.87^{* *}$ \\
length over 12 months & & & \\
\hline
\end{tabular}

$* \mathrm{P}<0.05$ significant difference between children of group VI with genotype CC and TT $* * \mathrm{P}<0.05$ significant difference between children of group VI with genotype CT and TT

Based on the data in table 10, the indicators of body length and growth in children with control group IV were significantly lower among children with the TT genotype than with other genotypes, at the age of 10, 11, 12 months and overall indicators of body length and growth in the first year of life. 
Table 10. The state of feeding in the first 6 months

\begin{tabular}{|l|c|c|c|}
\hline Groups & Natural feeding & Artificial feeding & Mixed feeding \\
\hline Group I & $13.95 \%$ & $69.77 \%$ & $16.27 \%$ \\
\hline$p$ I-II & $\mathrm{p}>0.05$ & $\mathrm{p}>0.05$ & $\mathrm{p}<0.05$ \\
\hline Group II & $33.87 \%$ & $53.22 \%$ & $12.90 \%$ \\
\hline Group III & $23.53 \%$ & $58.82 \%$ & $17.65 \%$ \\
\hline $\mathrm{p}$ I-III & $\mathrm{p}>0.05$ & $\mathrm{p}>0.05$ & $\mathrm{p}<0.05$ \\
\hline $\mathrm{p}$ II-III & $\mathrm{p}>0.05$ & $\mathrm{p}>0.05$ & $\mathrm{p}<0.05$ \\
\hline Group IV & $54.83 \%$ & $35.48 \%$ & $22.58 \%$ \\
\hline $\mathrm{p}$ I- IV & $\mathrm{p}<0.05$ & $\mathrm{p}<0.05$ & $\mathrm{p}<0.05$ \\
\hline $\mathrm{p}$ II- IV & $\mathrm{p}>0.05$ & $\mathrm{p}>0.05$ & $\mathrm{p}<0.05$ \\
\hline $\mathrm{p}$ III- IV & $\mathrm{p}>0.05$ & $\mathrm{p}>0.05$ & $\mathrm{p}<0.05$ \\
\hline
\end{tabular}

Further analysis of the type of breastfeeding in the first year of life showed that in the first group of observations, $13.95 \%$ of children were on natural feeding, $69.77 \%$ - on mixed, $16.27 \%$ - on artificial. In group II - 33.87\% of children were on natural feeding, $53.22 \%$ - on mixed, $12.90 \%$ - on artificial. In group III $-23.53 \%$ of children were breastfed, $58.82 \%$ - on mixed, $17.65 \%$ - on artificial, in group IV - 54.83\% of children were on natural feeding, $35.48 \%$ - on mixed, $22.58 \%$ - on artificial.

However, a correlation between the type of feeding and the increase in body weight and length, or their monthly growth rates, taking into account the genotypes of the ACTN3 gene (rs1815739) was not registered. However, a probable positive correlation was found between the duration of breastfeeding and the monthly increase in body length in children with the TT genotype of the ACTN3 gene (rs1815739): $\gamma=0.58, \gamma=0.76, \gamma=0.61$ with I, II, and III observation groups, respectively.

Discussion. At the beginning of the discussion, we note that in foreign sources, to show that the polymorphism of the ACTN3 gene replaces arginine $(\mathrm{R})$ at position 577 in the stop-codon $(\mathrm{X})$, alleles are also denoted as $\mathrm{R}$ and $\mathrm{X}$, while in our study as $\mathrm{C}$ and $\mathrm{T}$. The homozygous genotype SS or RR is called major, and the homozygous genotype TT or XX minor.

We also compared the results of our study with global population studies. The frequency of detection of recessive $\mathrm{T}$ allele and homozygous TT genotype in children from the study is much higher than in the world population. The frequency of the $\mathrm{C}$ allele is lower than the world data, and the genotypes of ST and CC, compared with world data, have slightly lower values. The frequency of occurrence of $\mathrm{C}$ and $\mathrm{T}$ alleles in our study is close to the data of the United States of America (USA) and South Asia. The frequency of CC 
genotype of children in our study is close to European data, TT genotype - to US data, CT genotype - to South Asian data (Fig. 3) [6].

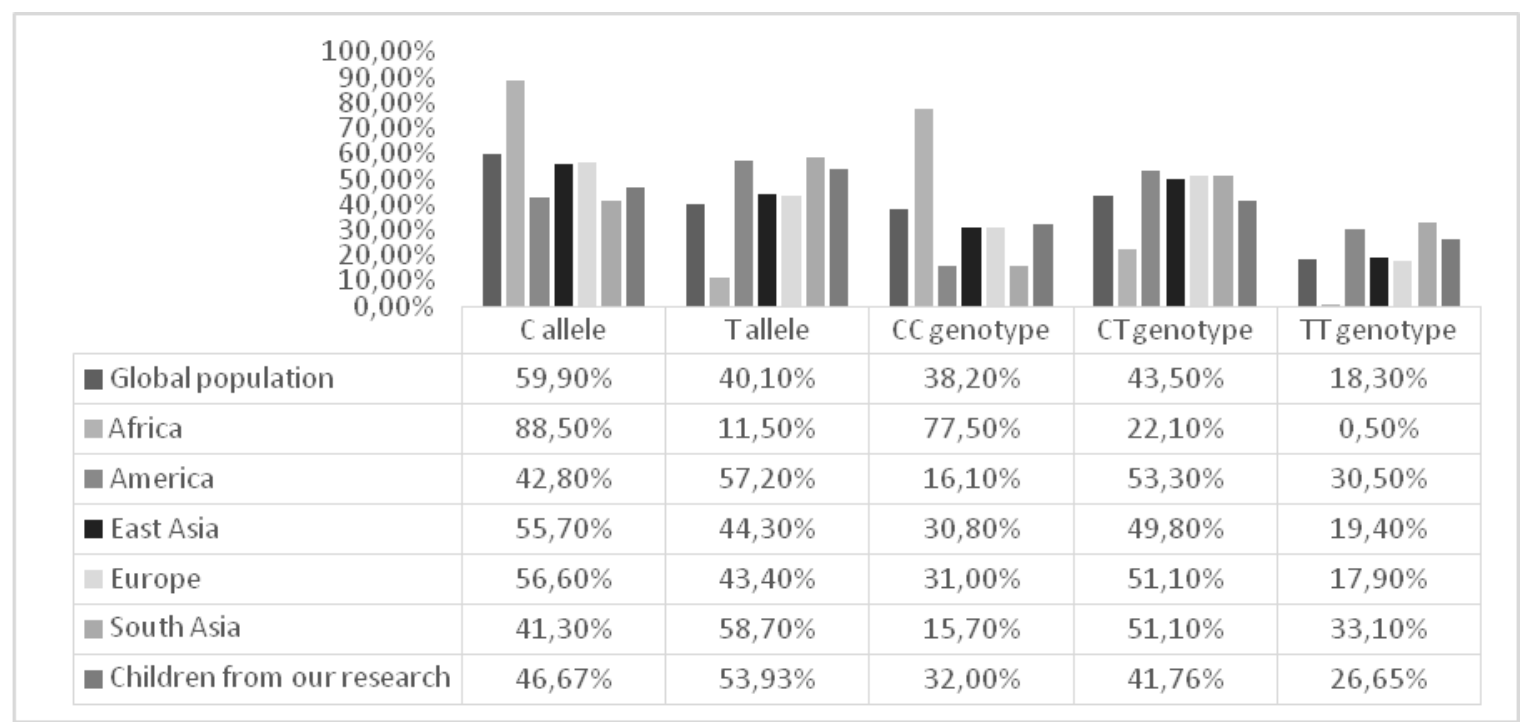

Fig. 3. Comparison of the frequency of alleles and genotypes of polymorphism of the ACTN3 gene (rs1815739) with world data

Zaccagni L. and co-authors studied the relationship between anthropometric parameters and genetic factors in Croatian sprinters. The study involved 104 Croatian sprinters: 36 women (mean age $37.0 \pm 14.8$ years) and 68 men (mean age $33.2 \pm 12.8$ years). As for the ACTN3 polymorphism, the most common genotype was RX (53 subjects, 51\%), followed by RR (32 subjects, 31\%) and XX (19 subjects, 18\%). The frequency of the R allele was $56 \%$ and $\mathrm{X}$ was $44 \%$, with no significant difference by sex. Anthropometric data included determination of the length of the lower limb and lower leg, the length of the foot. The most significant predictors of higher running speed were foot size and leg length. However, this study did not examine the relationship between anthropometric data and genotypes [7].

In a study by Ana Paula Renno Sierra and co-authors, the C / T polymorphism of the ACTN3 gene (rs1815739) was studied among amateur runners. It was found that athletes with genotype XX had less body weight $(70.1 \pm 8.5)$ than athletes with genotype RR and RX (71.6 \pm 8.8 and $77.4 \pm 10.0$ ), with the latter had less training experience than runners with genotype $\mathrm{XX}(7.15 \pm 5.1$ years vs. $6.14 \pm 4.3$ and $5.6 \pm 4.7)[8]$.

Güereca-Arvizuo and colleagues found that both male and female athletes with the RR genotype had a mesomorphic somatotype, whereas men with the XX genotype had an 
ectomorphic somatotype. Mesomorphic type or normothermic type is characterized by moderately rapid muscle gain, ectomorphic or asthenic type of body structure, characterized by underdeveloped muscles, slim physique [9].

Natalia Potocka and colleagues in her study did not find such a pattern. Analyzing the relationship between genotypes and somatotypes, the authors observed differences between men and women. Most women with RR and RX genotypes had endomorphic body type, while genotype XX was most often represented by women with ectomorphic body type. In contrast, in the male group, all genotypes were most represented in individuals with mesomorphic body type. Comparison of male endomorphs with ectomorphs revealed more individuals with the RR genotype (containing $\alpha$-actinin-3 in muscle) in the ectomorph group [10].

We did not determine the somatotype in our study, but we observed this trend, children with the TT (XX) genotype had less weight and weight gain than children with the CC (RR) genotype.

There are also scientific studies that determine the association of ACTN3 gene polymorphism with the risk of sports injuries. Qi et al. and Massidda et al. studied the relationship between exercise intensity and non-contact muscle damage. From these studies, it became known about the protective effect of the $\mathrm{R}$ allele and/or RR genotype from damage, and in the XX genotype athletes had almost three times more injuries than carriers of the $\mathrm{R}$ allele [11,12]. Based on these data, we can assume that the RR genotype affects human physical activity during life, ie children with the RR genotype will be more active, which in turn leads to better muscle mass gain, and children with the XX genotype will be less active, which in turn affects muscle mass gain and body weight in general.

In addition, it has been established that the ACTN3 XX genotype is associated with less muscle volume, reduced strength, strength, and endurance [13]. Besides, Arthur Cunha and co-authors studied genetic variants of ACTN3 and their effect on craniofacial skeletal bone growth and malocclusion. Thus, it was found that in the examined subjects, the presence of malocclusion class II and impaired bone growth of the facial skeleton was associated with a statistically significant higher incidence of minor homozygous genotype XX (or TT) of the ACTN3 gene (rs1815739) [5].

\section{Conclusions}

1. Molecular genetic study of CT polymorphism of the ACTN3 gene (rs1815739) in all examined children showed that the frequency of occurrence of allele $\mathrm{C}$ was $51.47 \%$, allele T $-48.52 \%$, the frequency of genotypes SS-30.59\%, TT- $26.65 \%$, ST-41.76\%, but only in children with intrauterine growth retardation significantly more often the T allele $(68.00 \%)$ 
than the $\mathrm{C}$ allele $(32.00 \%)$ and the TT genotype (52.00\%) than genotypes CC $(16.00 \%)$ and CT $(32.00 \%), \mathrm{p}<0.05$.

2. The lowest monthly values of body weight and weight gain were associated with the TT genotype of the ACTN3 gene (rs1815739) in premature infants and children with intrauterine growth retardation in the first half of life, and among children in the comparison group - in the second half, but the overall rates of body weight gain 12 months had no genotypic dependence.

3. Premature infants (groups I and II of observation) with the TT genotype of the ACTN3 gene (rs1815739) had unevenly lower body length during the first year of life, while children with intrauterine growth retardation were behind in their growth in the first half of the year, and children from the control group - in the second half of the year. The total annual increase in body length for the first year of life in all children with the TT genotype was the lowest and amounted to in the first group $-28.50 \pm 1.03 \mathrm{~cm}$, in the second $-24.03 \pm 0.93 \mathrm{~cm}$, in the third $-25.50 \pm 1.04 \mathrm{~cm}$, in IV $-23.00 \pm 0.98 \mathrm{~cm}$.

4. A positive correlation was found between the duration of breastfeeding and monthly increase in body length in premature infants and children with intrauterine growth retardation with the TT genotype of the ACTN3 gene (rs1815739): $\gamma=0.58, \gamma=0.76, \gamma=0,61$, therefore, for their normal growth, long-term natural feeding should be recommended, especially for this contingent of subjects.

Financing. The study has been performed in the framework of the planned research scientific work of the Children's Diseases Department of ZSMU entitled "The peculiarities of the development of diseases and the elaboration of the programs of rational nutrition, of therapeutic and rehabilitation measures improvement, and of prevention of distresses in children of different age, who reside in an industrial city" state registration No 114U001397.

Conflict of interests: none.

\section{References}

1. World Health Organization. (2014). Early Childhood Development in the European Region. $\quad$ https://www.euro.who.int/_data/assets/pdf_file/0009/265779/Early-childdevelopment-in-the-European-Region-needs,-trends-and-policy-development-Rus.pdf

2. Kotova NV, Starets OO, Khimenko TM. The role of macro- and microelements in the growth and development of preterm infants. Odessa National Medical University MH of Ukraine [Internet]. 2016;6(4(22)):61-65. Available from: http://neonatology.bsmu.edu.ua/article/view/2413-4260.VI.4.22.2016.9/95807 
3. Del Coso, J., Hiam, D., Houweling, P., Pérez, L. M., Eynon, N., \& Lucía, A. (2018). More than a 'speed gene': ACTN3 R577X genotype, trainability, muscle damage, and the risk for injuries. European Journal of Applied Physiology, 119(1), 49-60. https://doi.org/10.1007/s00421-018-4010-0

4. Min, S.-K., Lim, S.-T., \& Kim, C.-S. (2016). Association of ACTN3 polymorphisms with BMD, and physical fitness of elderly women. Journal of Physical Therapy Science, 28(10), 2731-2736. https://doi.org/10.1589/jpts.28.2731

5. Zebrick, B., Teeramongkolgul, T., Nicot, R., Horton, M. J., Raoul, G., Ferri, J., Vieira, A. R., \& Sciote, J. J. (2014). ACTN3 R577X genotypes associate with Class II and deepbite malocclusions. American Journal of Orthodontics and Dentofacial Orthopedics, 146(5), 603-611. https://doi.org/10.1016/j.ajodo.2014.07.021

6. Ensembl. (n.d.). Population genetics - Homo sapiens - Ensembl ge-nome browser 100. Ensembl.org. Retrieved June 5 , 2020. http://www.ensembl.org/Homo_sapiens/Variation/Population?db=core;r=11:6656012466561124; $=\mathrm{vs} 1815739 ; \mathrm{vdb}=$ variation; $\mathrm{vf}=331342373$

7. Zaccagni, L., Lunghi, B., Barbieri, D., Rinaldo, N., Missoni, S., Šaric, T., Šarac, J., Babic, V., Rakovac, M., Bernardi, F., \& Gualdi-Russo, E. (2019). Performance prediction models based on anthropometric, genetic and psychological traits of Croatian sprinters. Biology of Sport, 36(1), 17-23. https://doi.org/10.5114/biolsport.2018.78901

8. Sierra, A. P. R., Oliveira, R. A., Silva, E. D., Lima, G. H. O., Benetti, M. P., Kiss, M. A. P., Sierra, C. A., Ghorayeb, N., Seto, J. T., Pesquero, J. B., \& Cury-Boaventura, M. F. (2019). Association Between Hematological Parameters and Iron Metabolism Response After Marathon Race and ACTN3 Genotype. Frontiers in Physiology, 10. https://doi.org/10.3389/fphys.2019.00697

9. Güereca-Arvizuo, J.; Ramos-Jiménez, A.; Flores-Martínez, N.; Reyes-Leal, G.; Hérnandez-Torres, R.P. ACTN3 genotypes and their association with athletes somatotype: Results of a pilot study. ECORFAN Ecuad. J. 2017, 4, 10-17 https://www.researchgate.net/publication/324015406_ACTN3_genotypes_and their_associati on_with_athletes_somatotype_Results_of_a_pilot_study

10. Potocka, N., Penar-Zadarko, B., Skrzypa, M., Braun, M., Zadarko-Domaradzka, M., Ozimek, M., Nizioł-Babiarz, E., Barabasz, Z., Zawlik, I., \& Zadarko, E. (2019). Association of ACTN3 Polymorphism with Body Somatotype and Cardiorespiratory Fitness in Young Healthy Adults. International Journal of Environmental Research and Public Health, 16(9), 1489. https://doi.org/10.3390/ijerph16091489 
11. Qi, B., Liu, J. Q., and Liu, G. L. (2016). Genetic association between ACTN3 polymorphism and risk of non-acute ankle sprain. Genet. Mol. Res. 15. doi: $10.4238 / \mathrm{gmr} 15048962$

12 Massidda, M., Voisin, S., Culigioni, C., Piras, F., Cugia, P., Xu, Y., et al. (2017). ACTN3 R577X polymorphism is associated with the incidence and severity of injuries in professional football players. Clin. J. Sport Med. doi: 10.1097/JSM.0000000000000487. [Epub ahead of print].

13. Erskine RM, Williams AG, Jones DA, Stewart CE, Degens H. Th e individual and combined infl uence of ACE and ACTN3 genotypes on muscle phenotypes before and aft er strength training. Scand J Med Sci Sports. 2014;24(4):642-648. https://www.smjournal.ru/jour/article/view/201/189\# 